\title{
Investigations of Metal-Coordinated Peptides as
}

\section{Supramolecular Synthons}

\author{
Warren W. Gerhardt and Marcus Weck* \\ School of Chemistry and Biochemistry \\ Georgia Institute of Technology, Atlanta, GA 30332-0400 \\ Fax: (+1) 404-894-7452 \\ E-mail: marcus.weck@chemistry.gatech.edu \\ Supplemental Information
}

Table of Contents

Materials and Methods

Page S2

Experimental

Page S3

Crystal Structures

Page S13

References

Page S17 


\section{Materials and Methods:}

Boc-L-4-pyridyl alanine and boc-L-3-pyridyl alanine were purchased from Peptech Corp. $\mathrm{CH}_{2} \mathrm{Cl}_{2}$ and THF were dried via passage through $\mathrm{Cu}_{2} \mathrm{O}$ and alumina columns. N,NDiisopropyl-ethyl amine (DIEA) and triethylamine $\left(\mathrm{Et}_{3} \mathrm{~N}\right)$ were distilled from sodium/benzophenone keytl, and TFA was distilled from $\mathrm{P}_{2} \mathrm{O}_{5}$. DMSO was degassed by stirring under vacuum at $50 \mathrm{mmHg}$ for 30 minutes. All glassware was flame dried or placed in an oven overnight at $130{ }^{\circ} \mathrm{C}$. Compounds were analyzed by use of UV light $(254 \mathrm{~nm}), \mathrm{I}_{2}$, or a $0.3 \%$ solution of ninhydrin in $3 \% \mathrm{AcOH} / n$-butanol. HPLC eluant was a mixture of $\mathrm{H}_{2} \mathrm{O}$ with an increasing gradient of $\mathrm{CH}_{3} \mathrm{CN}$, on a $\mathrm{C} 18$ reverse phase column. NMR spectra were recorded at $298 \mathrm{~K}\left({ }^{1} \mathrm{H}\right.$ NMR: $\left.300 \mathrm{MHz} ;{ }^{13} \mathrm{C} \mathrm{NMR} ; 75 \mathrm{MHz}\right)$. Chemical shifts are reported in parts per million (ppm), using residual solvent as an internal standard. Data reported as follows: chemical shift, multiplicity $(\mathrm{s}=$ singlet, $\mathrm{d}=$ doublet, $\mathrm{t}=$ triplet, $\mathrm{q}=$ quartet, $\mathrm{dd}=$ doublet of doublets, $\mathrm{m}=$ multiplet, $\mathrm{b}=$ broad), coupling constants, integration, proton assignment. Compound $\mathbf{1 2}$ was prepared according to previous literature procedures. ${ }^{1}$ 


\section{Experimental:}

(13): To an anhydrous THF (50 mL) solution of $\mathbf{1 2}(1.12 \mathrm{~g}, 3.3 \mathrm{mmol})$ and $\mathrm{CH}_{3} \mathrm{I}(0.70 \mathrm{~g}$, $5.0 \mathrm{mmol}) \mathrm{Cs}_{2} \mathrm{CO}_{3}(1.29 \mathrm{~g}, 4.0 \mathrm{mmol})$ was added in one portion and stirred for $12 \mathrm{~h}$ at 25 ${ }^{\circ} \mathrm{C}$. The solids were then filtered off and the solvent removed under reduced pressure. The crude oil was redissolved in EtOAc and purified by flash column chromatography (silica gel, eluant: 80:20 hexanes:EtOAc) and the product dried in vacuo to give a clear oil $(1.10 \mathrm{~g}, 94 \%) .{ }^{1} \mathrm{H} \mathrm{NMR}\left(\mathrm{CDCl}_{3}, 300 \mathrm{MHz}\right)$ 8: 7.34-7.13 (m, 10H), $6.86(\mathrm{~s}, 1 \mathrm{H}), 6.70$ (s, 2H), $4.04(\mathrm{~s}, 4 \mathrm{H}), 3.71(\mathrm{~s}, 3 \mathrm{H}) ;{ }^{13} \mathrm{C} \mathrm{NMR}\left(\mathrm{CDCl}_{3}, 75 \mathrm{MHz}\right)$ 8: 159.7, 139.1, 136.4, 129.9, 128.9, 126.4, 121.7, 113.2, 55.2, 38.94; MS (EI, $70 \mathrm{eV}$ ) m/z: $\mathrm{M}^{+} 352$ (90), 243 (100), 210 (32), 134 (26), 91 (25); HRMS (EI, $70 \mathrm{eV}$ ) calcd for $\mathrm{C}_{21} \mathrm{H}_{20} \mathrm{OS}_{2}$ : 352.09459 , found: 352.09556 .

(5): A solution of $\mathrm{PdCl}_{2}(\mathrm{NCPh})_{2}(0.85 \mathrm{~g}, 2.2 \mathrm{mmol})$ and $\mathbf{1 3}(0.82 \mathrm{~g}, 2.2 \mathrm{mmol})$ in $\mathrm{CH}_{2} \mathrm{Cl}_{2}: \mathrm{CH}_{3} \mathrm{CN}$ 1:1 $(20 \mathrm{~mL})$ was allowed to stir at $25^{\circ} \mathrm{C}$ for $15 \mathrm{~min}$ becoming an opaque orange solution, at which time $\mathrm{AgBF}_{4}(1.08 \mathrm{~g}, 5.55 \mathrm{mmol})$ was added. A precipitate formed immediately and the mixture was allowed to stir for an additional 30 min at 25 ${ }^{\circ} \mathrm{C}$. During this time the reaction mixture changed from an orange to a yellow color. The reaction mixture was then diluted with $\mathrm{CH}_{2} \mathrm{Cl}_{2}(200 \mathrm{~mL})$ and poured directly into a saturated aq. $\mathrm{NaCl}$ solution $(200 \mathrm{~mL})$ and stirred overnight. The organic layer was separated, dried over $\mathrm{MgSO}_{4}$, filtered through celite and the solvent removed under reduced pressure giving a crude yellow oil which was further purified by flash column chromatography (silica gel, (a) eluant: $\mathrm{CH}_{2} \mathrm{Cl}_{2}$ to flush out all non-palladated organics and 
then (b) eluant: $99: 1 \mathrm{CH}_{2} \mathrm{Cl}_{2}: \mathrm{MeOH}$ to flush out the product) to yield the final product as a yellow foamy solid $(1.07 \mathrm{~g}, 98 \%)$. The product was recrystallized from $\mathrm{CHCl}_{3}$ forming large yellow crystals suitable for X-ray structural analysis. ${ }^{1} \mathrm{H}$ NMR $\left(d_{6}\right.$-DMSO, 300

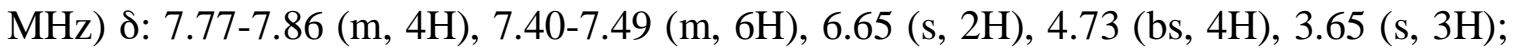
${ }^{13} \mathrm{C}$ NMR $\left(\mathrm{CDCl}_{3}, 75 \mathrm{MHz}\right) \delta: 157.3,151.4,150.0,132.3,131.3,129.6,129.5,108.2$, 55.2, 51.6; $\mathrm{MS}\left(\mathrm{ESI}^{+}\right)$457.0; HRMS $\left(\mathrm{ESI}^{+}\right)$calcd for $\mathrm{C}_{21} \mathrm{H}_{19} \mathrm{OPdS}_{2}$ : 457.9869, found: 457.9984 [the chlorine atom was labile under these ionization conditions]. Elemental analysis: calcd for $\mathrm{C}_{21} \mathrm{H}_{19} \mathrm{ClOPdS}_{2}$ : C, 51.12; H, 3.88; S, 13.00; Cl, 7.19, O, 3.24; Pd, 21.57. found: C, 50.76; H, 3.89; S, 12.77 . M.P. $182-184^{\circ} \mathrm{C}$.

(7): $\mathrm{Et}_{3} \mathrm{~N}(1.9 \mathrm{~mL}, 13.6 \mathrm{mmol})$ was added to a suspension of glycine methyl ester $\mathrm{HCl}$ (1.71 g, $13.6 \mathrm{mmol})$ in THF $(75 \mathrm{~mL})$ and allowed to stir for $15 \mathrm{~min}$. Boc-4-pyridyl alanine $(1.80 \mathrm{~g}, 6.8 \mathrm{mmol})$ and $\mathrm{HOBt}(0.91 \mathrm{~g}, 6.8 \mathrm{mmol})$ were added to the THF mixture and it was cooled to $0{ }^{\circ} \mathrm{C}$. Then a solution of DCC $(1.40 \mathrm{~g}, 6.8 \mathrm{mmol})$ in THF $(10 \mathrm{~mL})$ was added in one portion. After $5 \mathrm{~min}$, the reaction mixture was allowed to warm up to $25{ }^{\circ} \mathrm{C}$ and stirred overnight. The dicyclohexyl urea (DCU) precipitate was filtered off and the THF was removed under reduced pressure. The crude oil was redissolved in EtOAc and cooled in a freezer to precipitate out unreacted DCC, which was filtered off. The EtOAc solution was then washed with a saturated aqueous $\mathrm{NaHCO}_{3}$ solution to remove $\mathrm{HOBt}$, and the basic aqueous layer was back extracted with $\mathrm{CH}_{2} \mathrm{Cl}_{2}$, the organic layers were combined and the solvent removed under reduced pressure. This crude oil was further purified by flash column chromatography (silica gel, eluant: 95:5 EtOAc: $\mathrm{MeOH}$ ) and the product dried in vacuo to yield the final product as a white foam (2.00 g, 88\%). ${ }^{1} \mathrm{H} \mathrm{NMR}\left(\mathrm{CDCl}_{3}, 300 \mathrm{MHz}\right) \delta: 8.42(\mathrm{dd}, J=5.8,2 \mathrm{H}), 7.11(\mathrm{~d}, J=5.8$, 
$2 \mathrm{H}), 7.11(\mathrm{~d}, J=3.2,1 \mathrm{H}), 5.45(\mathrm{~d}, J=8.2,1 \mathrm{H}), 4.49(\mathrm{q}, J=6.8,1 \mathrm{H}), 3.96(\mathrm{t}, J=4.0$, 2H), $3.68(\mathrm{~s}, 3 \mathrm{H}), 3.14(\mathrm{dd}, J=6.0,13.9,1 \mathrm{H}), 2.93(\mathrm{dd}, J=7.7,13.9,1 \mathrm{H}), 1.32(\mathrm{~s}, 9 \mathrm{H})$; ${ }^{13} \mathrm{C} \mathrm{NMR}\left(\mathrm{CDCl}_{3}, 75 \mathrm{MHz}\right) \delta: 171.1,169.8,155.3,149.5,145.9,124.6,80.4,54.5,52.4$, 41.1, 37.6, 28.2; $\mathrm{MS}\left(\mathrm{ESI}^{+}\right)\left[\mathrm{M}+\mathrm{H}^{+}\right]$338.2; HRMS $\left(\mathrm{ESI}^{+}\right)\left[\mathrm{M}+\mathrm{H}^{+}\right]$calcd for $\mathrm{C}_{16} \mathrm{H}_{24} \mathrm{~N}_{3} \mathrm{O}_{5}: 338.1736$, found: 338.1710 .

(8): $\mathrm{Et}_{3} \mathrm{~N}(1.9 \mathrm{~mL}, 13.6 \mathrm{mmol})$ was added to a suspension of glycine methyl ester $\mathrm{HCl}$ $(1.71 \mathrm{~g}, 13.6 \mathrm{mmol})$ in THF $(75 \mathrm{~mL})$ and allowed to stir for $15 \mathrm{~min}$. Boc-3-pyridyl alanine $(1.80 \mathrm{~g}, 6.8 \mathrm{mmol})$ and HOBt $(0.91 \mathrm{~g}, 6.8 \mathrm{mmol})$ were added to the THF solution and the reaction mixture was cooled to $0{ }^{\circ} \mathrm{C}$ followed by the addition of a solution of DCC $(1.40 \mathrm{~g}, 6.8 \mathrm{mmol})$ in THF $(10 \mathrm{~mL})$ in one portion. After $5 \mathrm{~min}$, the reaction mixture was allowed to warm up to $25{ }^{\circ} \mathrm{C}$ and stirred overnight. The dicyclohexyl urea (DCU) precipitate was filtered off, and the THF was removed under reduced pressure. The crude oil was redissolved in EtOAc and cooled in a freezer to precipitate out unreacted DCC, which was filtered off. The EtOAc solution was then wash with a saturated aqueous $\mathrm{NaHCO}_{3}$ solution to remove $\mathrm{HOBt}$, and the basic aqueous layer was back extracted with $\mathrm{CH}_{2} \mathrm{Cl}_{2}$, the organic layers were combined and the solvent was removed under reduced pressure. The crude oil was further purified by flash column chromatography (silica gel, eluant: 95:5 EtOAc: $\mathrm{MeOH}$ ) and the product dried in vacuo to yield a white foam $(2.10 \mathrm{~g}, 95 \%) .{ }^{1} \mathrm{H}$ NMR $\left(\mathrm{CDCl}_{3}, 300 \mathrm{MHz}\right)$ 8: 8.44 (dd, $J=1.7,4.7$, $1 \mathrm{H}), 8.40(\mathrm{~d}, J=1.7,1 \mathrm{H}), 7.54(\mathrm{dt}, J=1.9,7.7,1 \mathrm{H}), 7.19(\mathrm{dd}, J=4.9,7.1,1 \mathrm{H}), 6.85(\mathrm{t}, J$ $=5.2,1 \mathrm{H}), 5.23(\mathrm{~d}, J=8.8,1 \mathrm{H}), 4.44(\mathrm{q}, J=6.6,1 \mathrm{H}), 3.98(\mathrm{dd}, J=3.9,5.5,2 \mathrm{H}), 3.71(\mathrm{~s}$, $3 \mathrm{H}), 3.15(\mathrm{dd}, J=6.0,14.3,1 \mathrm{H}), 2.97(\mathrm{dd}, J=7.1,14.3,1 \mathrm{H}), 1.35(\mathrm{~s}, 9 \mathrm{H}) ;{ }^{13} \mathrm{C} \mathrm{NMR}$ $\left(\mathrm{CDCl}_{3}, 75 \mathrm{MHz}\right)$ 8: 171.7, 170.3, 155.7, 150.4, 147.9, 137.7, 133.0, 123.8, 80.4, 55.2, 
52.5, 41.3, 35.9, 28.4; $\mathrm{MS}\left(\mathrm{ESI}^{+}\right)\left[\mathrm{M}+\mathrm{H}^{+}\right]$338.2; $\mathrm{HRMS}\left(\mathrm{ESI}^{+}\right)\left[\mathrm{M}+\mathrm{H}^{+}\right]$calcd for $\mathrm{C}_{16} \mathrm{H}_{24} \mathrm{~N}_{3} \mathrm{O}_{5}: 338.1726$, found: 338.1705 .

(9): $\mathrm{Et}_{3} \mathrm{~N}(1.1 \mathrm{~mL}, 7.6 \mathrm{mmol})$ was added to a suspension of glycine methyl ester $\mathrm{HCl}$ (0.95 g, $7.6 \mathrm{mmol})$ in THF $(75 \mathrm{~mL})$ and allowed to stir for $15 \mathrm{~min}$. Phenylalanine (1.00 $\mathrm{g}, 3.8 \mathrm{mmol})$ and HOBt $(0.51 \mathrm{~g}, 3.8 \mathrm{mmol})$ were added to the THF solution and the reaction mixture was cooled to $0{ }^{\circ} \mathrm{C}$. A solution of DCC $(0.78 \mathrm{~g}, 3.8 \mathrm{mmol})$ in THF (10 $\mathrm{mL}$ ) was added to the reaction in one portion. After $5 \mathrm{~min}$, the reaction mixture was allowed to warm up to $25{ }^{\circ} \mathrm{C}$ and stirred overnight. The dicyclohexyl urea (DCU) precipitate was filtered off, and the THF was removed under reduced pressure. The crude oil was redissolved in EtOAc and cooled in a freezer to precipitate out unreacted DCC, which was filtered off. The EtOAc solution was then washed with a saturated aqueous $\mathrm{NaHCO}_{3}$ solution to remove $\mathrm{HOBt}$, and the basic aqueous layer was back extracted with $\mathrm{CH}_{2} \mathrm{Cl}_{2}$. The organic layers were combined and the solvent removed under reduced pressure giving a white solid $(1.15 \mathrm{~g}, 90 \%)$. ${ }^{1} \mathrm{H}$ NMR $\left(\mathrm{CDCl}_{3}, 300 \mathrm{MHz}\right)$ 8: 7.18-7.35 (m, 5H), $6.38(\mathrm{~m}, 1 \mathrm{H}), 4.96(\mathrm{~d}, \mathrm{~m}, 1 \mathrm{H}), 4.40(\mathrm{q}, J=7.0,1 \mathrm{H}), 4.01(\mathrm{~m}, 2 \mathrm{H}), 3.73(\mathrm{~s}, 3 \mathrm{H})$, $3.11(\mathrm{~m}, 2 \mathrm{H}), 1.40(\mathrm{~s}, 9 \mathrm{H}) ;{ }^{13} \mathrm{C} \mathrm{NMR}\left(\mathrm{CDCl}_{3}, 75 \mathrm{MHz}\right)$ 8:171.7, 170.4, 155.7, 136.9, $129.2,128.4,126.7,80.3,55.4,52.1,41.0,38.3,28.1 ; \quad M S\left(\mathrm{FAB}^{+}\right)\left[\mathrm{M}+\mathrm{H}^{+}\right] 337.1$; HRMS $\left(\mathrm{FAB}^{+}\right)\left[\mathrm{M}+\mathrm{H}^{+}\right]$calcd for $\mathrm{C}_{17} \mathrm{H}_{25} \mathrm{~N}_{2} \mathrm{O}_{5}: 337.17577$, found: 337.17627 .

(11): $\mathrm{ZnCl}_{2}$ in $\mathrm{Et}_{2} \mathrm{O}(28.1 \mathrm{~mL}, 28.1 \mathrm{mmol})$ was added to a $0{ }^{\circ} \mathrm{C}$ solution of 2,3,4,6-tetraO-pivaloyl- $\beta$-D-galactopyranosylamine (7.24 g, $14.1 \mathrm{mmol}$ ), 3-pyridinecarboxaldehyde (1.3 $\mathrm{mL}, 14.1 \mathrm{mmol})$, formic acid $(0.58 \mathrm{~mL}, 15.5 \mathrm{mmol})$, and methyl isocyanoacetate (1.4 $\mathrm{mL}, 14.8 \mathrm{mmol})$ in anhydrous $\mathrm{THF}(50 \mathrm{~mL})$. After $30 \mathrm{~min}$, the reaction mixture was allowed to warm up to $25{ }^{\circ} \mathrm{C}$ and monitored by TLC which showed complete 
consumption of the aldehyde after $12 \mathrm{~h}$. The solvent was removed under reduced pressure and the crude mixture redissolved in EtOAc forming an orange solution, which was washed with a $1 \mathrm{~N}$ aqueous $\mathrm{KHSO}_{4}$ solution $(2 \mathrm{x})$ removing the orange color, leaving a yellow solution. The solvent was removed under reduced pressure giving a light brown solid, which was further purified by flash column chromatography (silica gel, eluant: EtOAc). The product was dried in vacuo to give an orange foam $(9.3 \mathrm{~g}, 88 \%)$. This sugar-formyl protected dipeptide intermediate was dissolved in $\mathrm{MeOH}(50 \mathrm{~mL})$ cooled to $0{ }^{\circ} \mathrm{C}$ and saturated with dry $\mathrm{HCl}$ gas for $15 \mathrm{~min}$ and stirred at $0{ }^{\circ} \mathrm{C}$ for $1 \mathrm{~h}$. The reaction mixture was allowed to warm up to $25{ }^{\circ} \mathrm{C}$ and stirred for an additional $4 \mathrm{~h}$ to remove the formyl group. Water $(40 \mathrm{~mL})$ was then added to the methanolic reaction mixture and stirred for an additional $10 \mathrm{~h}$. The $\mathrm{MeOH}$ was then removed under reduced pressure and the aqueous reaction mixture was washed with $\mathrm{CH}_{2} \mathrm{Cl}_{2}$ until the organic washes were colorless. The water was then removed under reduced pressure to give the hydrolyzed dipeptide, which was redissolved in $\mathrm{MeOH}(30 \mathrm{~mL})$ and saturated with dry $\mathrm{HCl}$ gas for $15 \mathrm{~min}$ and allowed to stir for $3 \mathrm{~h}$ to reesterify the carboxylate terminus. $\mathrm{Et}_{2} \mathrm{O}$ was added to the methanolic solution to precipitate out the crude dipeptide $\mathrm{HCl}$ salt which was further purified by repeated triturations from a boiling $\mathrm{Et}_{2} \mathrm{O}: \mathrm{MeOH}$ solution and isolated as a yellow solid $(3.58 \mathrm{~g}, 86 \%) .{ }^{1} \mathrm{H} \mathrm{NMR}\left(\mathrm{D}_{2} \mathrm{O}, 300 \mathrm{MHz}\right) \delta: 9.03(\mathrm{~s}, 1 \mathrm{H}), 8.95(\mathrm{~d}, 1 \mathrm{H})$, $8.72(\mathrm{~d}, 1 \mathrm{H}), 8.20(\mathrm{t}, 1 \mathrm{H}), 5.59(\mathrm{~s}, 1 \mathrm{H}), 4.08(\mathrm{dd}, J=18.0,45.2,2 \mathrm{H}), 3.71(\mathrm{~s}, 3 \mathrm{H}) ;{ }^{13} \mathrm{C}$ NMR $\left(d_{6}\right.$-DMSO, $\left.75 \mathrm{MHz}\right) \delta: 170.1,169.3,166.3,166.1,143.6,53.0,52.0,40.8 ; \quad \mathrm{MS}$ $\left(\mathrm{FAB}^{+}\right)\left[\mathrm{M}+\mathrm{H}^{+}\right] 224.1 ; \operatorname{HRMS}\left(\mathrm{FAB}^{+}\right)\left[\mathrm{M}+\mathrm{H}^{+}\right]$calcd for $\mathrm{C}_{10} \mathrm{H}_{14} \mathrm{~N}_{3} \mathrm{O}_{3}:$ 224.10183, found: 224.10352 . 
(2): Boc protected dipeptide 6 (2.10 g, $6.2 \mathrm{mmol})$ was dissolved in $\mathrm{MeOH}(50 \mathrm{~mL})$ and saturated with $\mathrm{HCl}$ gas for 15 min while keeping the temperature constant at $25^{\circ} \mathrm{C}$. After $\mathrm{HCl}$ addition, the reaction was stirred for an additional $30 \mathrm{~min}$. The solvent was then removed under reduced pressure and dried in vacuo (complete deprotection was confirmed by ${ }^{1} \mathrm{H}$ NMR). The $\mathrm{HCl}$ salt of deprotected dipeptide $\mathbf{6}$ was dissolved in a solution of DIEA (2.0 mL, $12.3 \mathrm{mmol})$ in anhydrous DMF $(20 \mathrm{~mL})$, and the mixture incubated for $10 \mathrm{~min}$. In a separate flask, a solution of PyBOP (3.85 g, $7.4 \mathrm{mmol})$, phthaloyl glycine (1.51 g, $7.4 \mathrm{mmol})$, HOAt (1.01 g, $7.4 \mathrm{mmol})$, and DIEA (3.7 mL, 22.2 mmol) in anhydrous DMF (10 mL) was allowed to incubate for $5 \mathrm{~min}$ and then added in one portion to the deprotected dipeptide $\mathbf{6}$ solution. The reaction became a red color after $30 \mathrm{~min}$ and a precipitate formed after $1 \mathrm{~h}$. Stirring was continued for $12 \mathrm{~h}$, the DMF was removed under reduced pressure and the mixture taken up in $\mathrm{CH}_{2} \mathrm{Cl}_{2}$. The insoluble material was filtered off and washed with $\mathrm{CH}_{2} \mathrm{Cl}_{2}$ and dried to give a white powder which was further purified by HPLC (water: $\mathrm{CH}_{3} \mathrm{CN}$ gradient; $\mathrm{C} 18$ column) yielding a white solid $(2.30 \mathrm{~g}, 89 \%)$, which was crystallized from a $95: 5 \mathrm{CH}_{3} \mathrm{CN}$ : water mixture as thin white needles for X-ray structural analysis. ${ }^{1} \mathrm{H}$ NMR $\left(d_{6}\right.$-DMSO, $\left.300 \mathrm{MHz}\right) \delta: 8.60-8.69$ (m, 1H), 8.60-8.69 (m, 1H), $8.49(\mathrm{~d}, J=5.2,2 \mathrm{H}), 7.83-7.92(\mathrm{~m}, 4 \mathrm{H}), 7.3(\mathrm{~d}, J=5.3,2 \mathrm{H})$, 4.58-4.68 (m, 1H), $4.17(\mathrm{dd}, J=10,16.8,2 \mathrm{H}), 3.88(\mathrm{dd}, J=2.2,3.5,2 \mathrm{H}), 3.63(\mathrm{~s}, 3 \mathrm{H})$, $3.06(\mathrm{dd}, J=4.7,13.8,2 \mathrm{H}), 2.81(\mathrm{dd}, J=9.6,13.8,2 \mathrm{H}) ;{ }^{13} \mathrm{C}$ NMR $\left(d_{6}\right.$-DMSO, $\left.75 \mathrm{MHz}\right)$

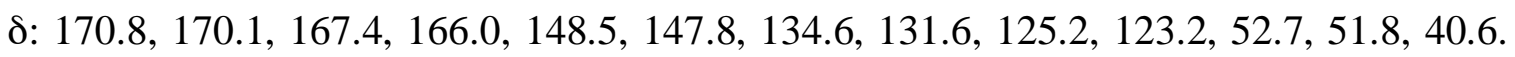
39.9, 37.1; $\mathrm{MS}\left(\mathrm{ESI}^{+}\right)\left[\mathrm{M}+\mathrm{H}^{+}\right]$425.1473; HRMS $\left(\mathrm{ESI}^{+}\right)\left[\mathrm{M}+\mathrm{H}^{+}\right]$calcd for $\mathrm{C}_{21} \mathrm{H}_{21} \mathrm{~N}_{4} \mathrm{O}_{6}$ : 425.1472, found: 425.1456 ; Elemental analysis: calcd for $\mathrm{C}_{21} \mathrm{H}_{20} \mathrm{~N}_{4} \mathrm{O}_{6}$ : C, 
59.43; H, 4.75; N, 13.20; O, 22.62. found: $\mathrm{C}, 59.27 ; \mathrm{H}, 4.71 ; \mathrm{N}, 13.21 ; \mathrm{O}, 22.81$; The onset of decomposition between $239-243{ }^{\circ} \mathrm{C}$ occurred before a melting point.

(6): The boc protected dipeptide $9(0.47 \mathrm{~g}, 1.4 \mathrm{mmol})$ was dissolved in a $1: 2$ TFA: $\mathrm{CH}_{2} \mathrm{Cl}_{2}$ solution $(10 \mathrm{~mL})$ at $25{ }^{\circ} \mathrm{C}$ and allowed to react for $1.5 \mathrm{~h}$. The solvent was then removed under reduced pressure and dried in vacuo. The TFA salt of the deprotected dipeptide 9 was dissolved in a solution of DIEA $(0.2 \mathrm{~mL}, 1.4 \mathrm{mmol})$ in anhydrous DMF $(12 \mathrm{~mL})$, and the mixture incubated for $10 \mathrm{~min}$. In a separate flask a solution of PyBOP (0.88 g, $1.7 \mathrm{mmol})$, phthaloyl glycine (0.35 g, $1.7 \mathrm{mmol})$, HOAt (0.23 $\mathrm{g}, 1.7 \mathrm{mmol})$, and DIEA ( $0.8 \mathrm{~mL}, 5.1 \mathrm{mmol})$ in anhydrous DMF $(8 \mathrm{~mL})$ was allowed to incubate for $5 \mathrm{~min}$ and then added in one portion to the deprotected dipeptide $\mathbf{9}$ solution. The reaction became a red color after $30 \mathrm{~min}$. Stirring was continued for $12 \mathrm{~h}$ at which time the DMF was removed under reduced pressure yielding a brown viscous oil. The oil was partially dissolved in EtOAc and washed with a saturated aqueous $\mathrm{NaHCO}_{3}$ solution. $\mathrm{Et}_{2} \mathrm{O}$ was then added to the organic layer precipitating out the semi-pure tripeptide which was collected by filtration and further purified by HPLC (water: $\mathrm{CH}_{3} \mathrm{CN}$ gradient; $\mathrm{C} 18$ column) yielding a white solid $(0.59 \mathrm{~g}, 96 \%) .{ }^{1} \mathrm{H}$ NMR $\left(d_{6}\right.$-DMSO, $\left.300 \mathrm{MHz}\right) \delta: 8.53-$ $8.62(\mathrm{~m}, 1 \mathrm{H}), 8.53-8.62(\mathrm{~m}, 1 \mathrm{H}), 7.79-7.95(\mathrm{~m}, 4 \mathrm{H}), 7.13-7.33(\mathrm{~m}, 5 \mathrm{H}), 4.54$ (sextet, $1 \mathrm{H})$, $4.18(\mathrm{dd}, J=17.0,28.6,2 \mathrm{H}), 3.86(\mathrm{dd}, J=2.0,5.8,2 \mathrm{H}), 3.63(\mathrm{~s}, 3 \mathrm{H}), 3.01(\mathrm{dd}, J=4.6$, $14.0,1 \mathrm{H}), 2.76(\mathrm{dd}, J=9.8,14.0,1 \mathrm{H}) ;{ }^{13} \mathrm{C}$ NMR $\left(d_{6}\right.$-DMSO, $\left.75 \mathrm{MHz}\right) \delta: 171.5,170.2$, $167.4,165.9,137.6,134.5,131.6,129.2,128.0,123.1,53.7,51.6,40.6 ; \mathrm{MS}\left(\mathrm{ESI}^{+}\right)[\mathrm{M}+$ $\left.\mathrm{H}^{+}\right]$424.2; HRMS $\left(\mathrm{ESI}^{+}\right)\left[\mathrm{M}+\mathrm{H}^{+}\right]$calcd for $\mathrm{C}_{22} \mathrm{H}_{22} \mathrm{~N}_{3} \mathrm{O}_{6}$ : 424.1512, found: 424.1503; Elemental analysis: calcd for $\mathrm{C}_{22} \mathrm{H}_{21} \mathrm{~N}_{3} \mathrm{O}_{6}: \mathrm{C}, 62.41 ; \mathrm{H}, 5.00 ; \mathrm{N}, 9.92 ; \mathrm{O}, 22.67$. found: $\mathrm{C}$, 62.67; H, 5.17; N, 9.85; O, 22.31. M.P. $232-234{ }^{\circ} \mathrm{C}$. 
(3): The $\mathrm{HCl}$ salt of the deprotected dipeptide $\mathbf{1 1}(1.50 \mathrm{~g}, 5.1 \mathrm{mmol})$ was dissolved in a solution of DIEA $(1.7 \mathrm{~mL}, 10.2 \mathrm{mmol})$ in anhydrous DMF $(20 \mathrm{~mL})$. The reaction mixture instantly turned yellow and the mixture incubated for $10 \mathrm{~min}$. In a separate flask, a solution of PyBOP (3.18 g, $6.1 \mathrm{mmol})$, phthaloyl glycine $(1.26 \mathrm{~g}, 6.1 \mathrm{mmol})$, HOAt $(0.83 \mathrm{~g}, 6.1 \mathrm{mmol})$, and DIEA $(3.0 \mathrm{~mL}, 18.4 \mathrm{mmol})$ in anhydrous DMF $(10 \mathrm{~mL})$ was allowed to incubate for $5 \mathrm{~min}$ and then added in one portion to the deprotected dipeptide 11 solution. The reaction turned red after $30 \mathrm{~min}$ and a precipitate formed after $1 \mathrm{~h}$. Stirring was continued for $12 \mathrm{~h}$, at which time the DMF was removed under reduced pressure, yielding a crude brown viscous oil. The oil was dissolved in a minimum amount of $\mathrm{MeOH}: \mathrm{H}_{2} \mathrm{O}$ :TFA and semi-purified by flash column chromatography (silica gel, eluant; 94:5:1 EtOAc:MeOH:Et $\left.{ }_{3} \mathrm{~N}\right)$. The product was dried in vacuo to give a yellow powder, which was further purified by HPLC (water: $\mathrm{CH}_{3} \mathrm{CN}$ gradient; $\mathrm{C} 18$ column) yielding a white solid $(1.67 \mathrm{~g}, 80 \%)$, which was recrystallized from a 95:5 $\mathrm{CH}_{3} \mathrm{CN}$ :water mixture as thin white needles for X-ray structural analysis. ${ }^{1} \mathrm{H}$ NMR $\left(d_{6}\right.$-DMSO, 300

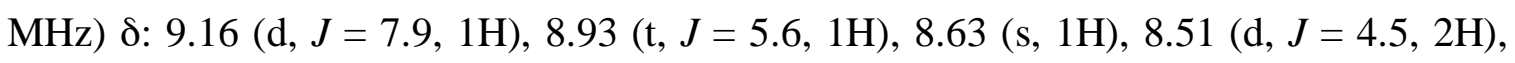
7.82-7.92 (m, 4H), $7.79(\mathrm{dt}, J=1.7,7.7,1 \mathrm{H}), 7.40(\mathrm{dd}, J=4.7,7.9,1 \mathrm{H}), 5.61(\mathrm{~d}, J=8.0$, $1 \mathrm{H}), 4.34(\mathrm{dd}, J=3.4,20.5,2 \mathrm{H}), 3.90(\mathrm{dd}, J=1.3,6.0,2 \mathrm{H}), 3.61(\mathrm{~s}, 3 \mathrm{H}) ;{ }^{13} \mathrm{C} \mathrm{NMR}\left(d_{6^{-}}\right.$

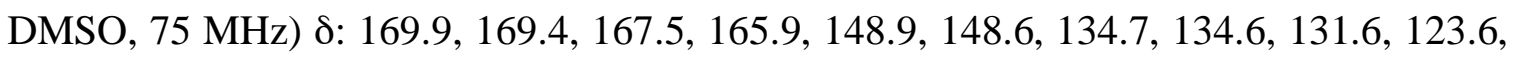
123.5, 123.2, 54.0, 51.8, 40.7, 39.9; $\mathrm{MS}\left(\mathrm{ESI}^{+}\right)\left[\mathrm{M}+\mathrm{H}^{+}\right]$411.13; HRMS $\left(\mathrm{ESI}^{+}\right)[\mathrm{M}+$ $\mathrm{H}^{+}$] calcd for $\mathrm{C}_{20} \mathrm{H}_{19} \mathrm{~N}_{4} \mathrm{O}_{6}: 411.1302$, found: 411.1299; Elemental analysis: calcd for $\mathrm{C}_{20} \mathrm{H}_{18} \mathrm{~N}_{4} \mathrm{O}_{6}$ : C, 58.53; H, 4.42; N, 13.65; O, 23.39. found: $\mathrm{C}, 58.22 ; \mathrm{H}, 4.59 ; \mathrm{N}, 13.64$; $\mathrm{O}, 23.55$; The onset of decomposition between $244-247{ }^{\circ} \mathrm{C}$ occurred before a melting point. 
(14): Compound $5(0.30 \mathrm{~g}, 0.6 \mathrm{mmol})$ was dissolved in $\mathrm{CH}_{2} \mathrm{Cl}_{2}: \mathrm{CH}_{3} \mathrm{CN} 1: 1(20 \mathrm{~mL})$ at $25^{\circ} \mathrm{C}$ and $\mathrm{AgBF}_{4}(0.13 \mathrm{~g}, 0.7 \mathrm{mmol})$ was added in one portion. Immediately a precipitate formed and the yellow mixture was allowed to stir for $3 \mathrm{~h}$. It was then filtered through celite, and the solvent was removed under reduced pressure. The residue was redissolved in $\mathrm{CH}_{2} \mathrm{Cl}_{2}$. This process was repeated to ensure full removal of any residual $\mathrm{AgBF}_{4}$. The residue was dried in vacuo at $40{ }^{\circ} \mathrm{C}$ to give a yellow solid $(0.34 \mathrm{~g}, 95 \%) .{ }^{1} \mathrm{H}$ NMR $\left(d_{6^{-}}\right.$ DMSO, $300 \mathrm{MHz})$ 8: 7.81-7.90 (m, 4H), 7.47-7.55 (m, 6H), 6.66 (s, 2H), 4.74 (bs, 4H), $3.66(\mathrm{~s}, 3 \mathrm{H}), 2.06(\mathrm{~s}, 3 \mathrm{H}) ;{ }^{13} \mathrm{C}$ NMR ( $d_{6}$-DMSO, $\left.75 \mathrm{MHz}\right)$ 8: 157.2, 151.1, 131.4, 131.1, $130.4,130.1,126.1,118.1,109.0,55.0,48.2,1.2 ; \mathrm{MS}\left(\mathrm{FAB}^{+}\right) \mathrm{m} / \mathrm{z}$ (relative intensity) 457.0 (100), 498.0 (5) $\mathrm{CH}_{3} \mathrm{CN}$ coordinated; $\mathrm{HRMS}\left(\mathrm{FAB}^{+}\right.$) calcd for $\mathrm{C}_{21} \mathrm{H}_{19} \mathrm{OPdS}_{2}$ : 457.9869, found: $457.9985\left[\mathrm{CH}_{3} \mathrm{CN}\right.$ was labile under these ionization conditions].

General procedure for the ${ }^{1} \mathrm{H}$ NMR characterization of tripeptides 1-4 coordinated to Pd pincer complex 5: Each tripeptide (5.0 or $5.2 \mathrm{mg}, 0.012 \mathrm{mmol}$ ) was dissolved in $d_{6}$-DMSO $(1 \mathrm{~mL})$ in an NMR tube and one equivalent of pincer complex $5(6.0 \mathrm{mg}$, $0.012 \mathrm{mmol}$ ) was titrated in from a $0.6 \mathrm{M} d_{6}$-DMSO stock solution (1:1 molar ratio based on ${ }^{1} \mathrm{H}$ NMR integration of an aromatic signal from each molecule). $\mathrm{AgBF}_{4}$ was then added to the solution in one portion and a precipitate instantly crashed out. The NMR tube mixture was oscillated for $2 \mathrm{~h}$ and then filtered through celite and a $0.2 \mu \mathrm{m}$ PTFE syringe filter and the clear yellow solution was reanalyzed.

General procedure for the ITC characterization of the coordination of tripeptides 14, pyridine, or 4-picoline with pincer complex 14: The ITC syringe was filled with a degassed DMSO pyridyl solution $(50 \mathrm{mM})$ and titrated $(5 \mu \mathrm{L}$ injections over $10 \mathrm{sec}$ followed by a $300 \mathrm{sec}$ equilibration period) into the sample cell containing a degassed 
DMSO solution of pincer complex $14(5 \mathrm{mM})$. A reference run of each pyridyl compound titrated into a pure degassed DMSO sample was subtracted from each measurement to account for heats of dilution. Each experiment was done in triplicate to validate all $K_{\mathrm{a}}$ values. 


\section{Crystal Structures:}

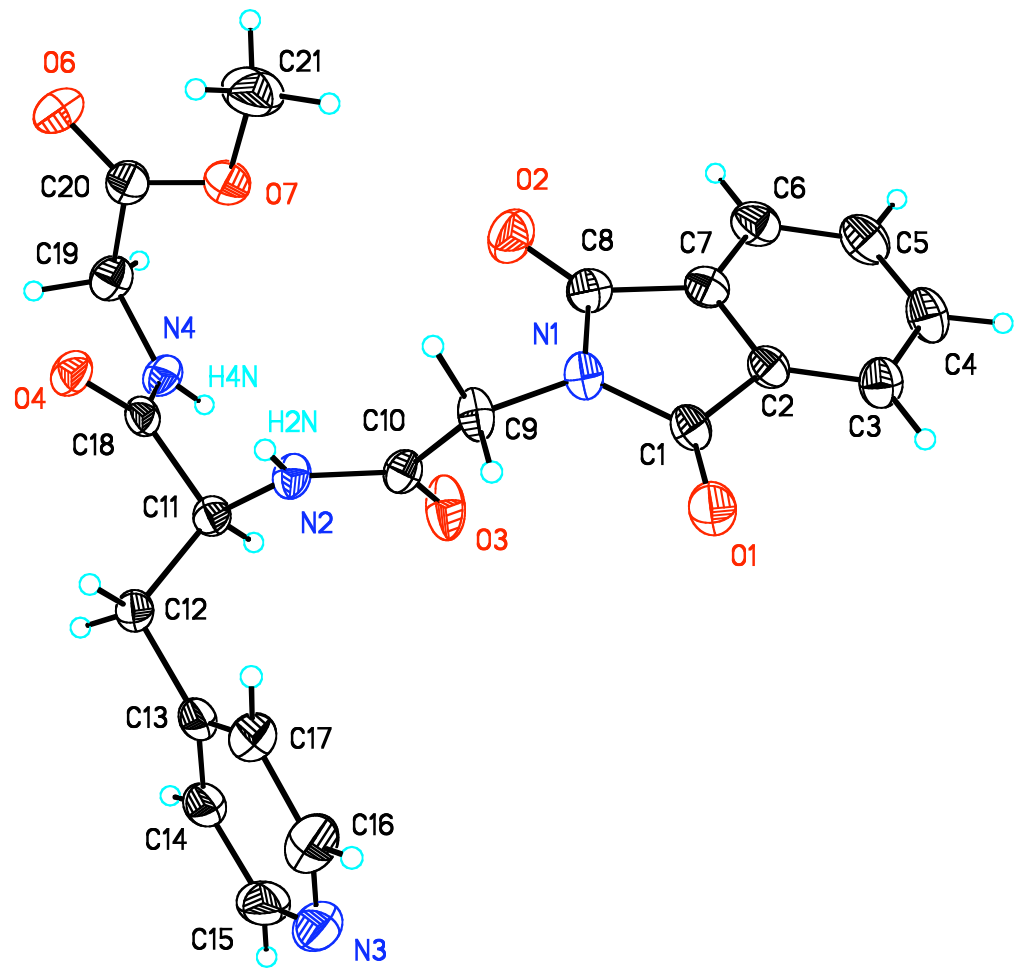

Supplemental Figure 1. Crystal structure of tripeptide 2. 


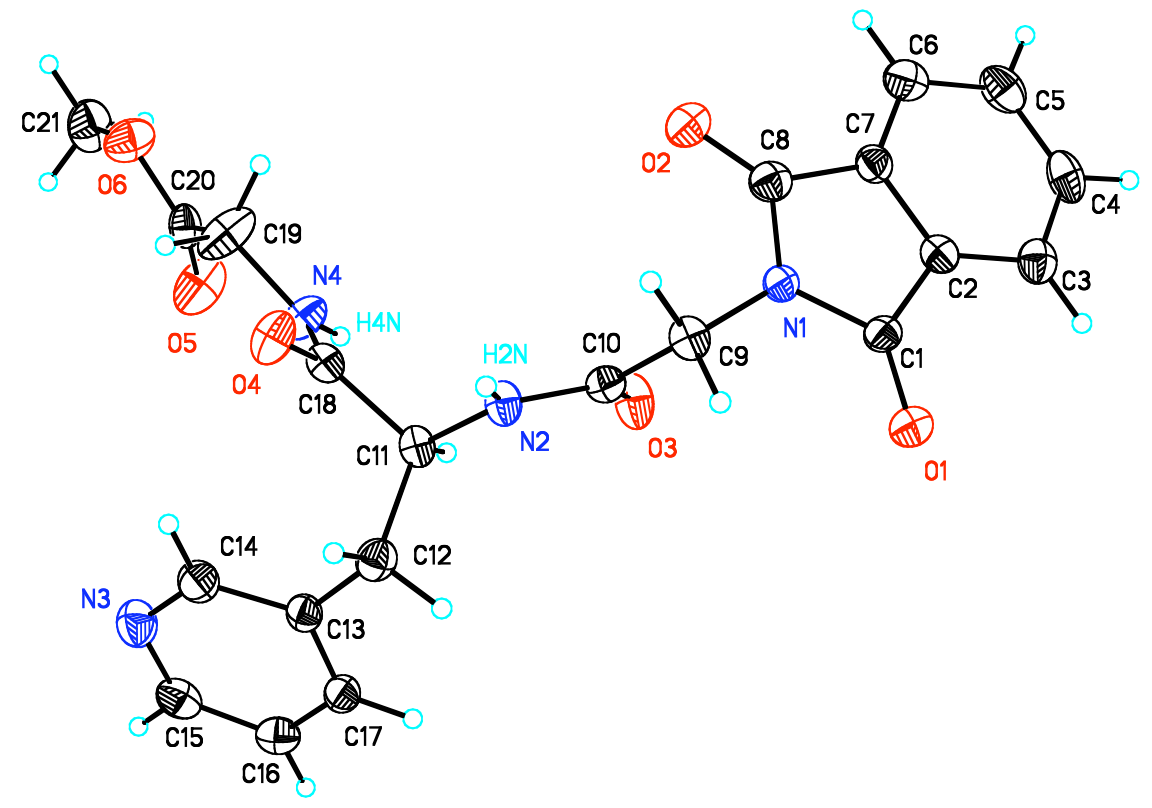

Supplemental Figure 2. Crystal structure of tripeptide 4. 


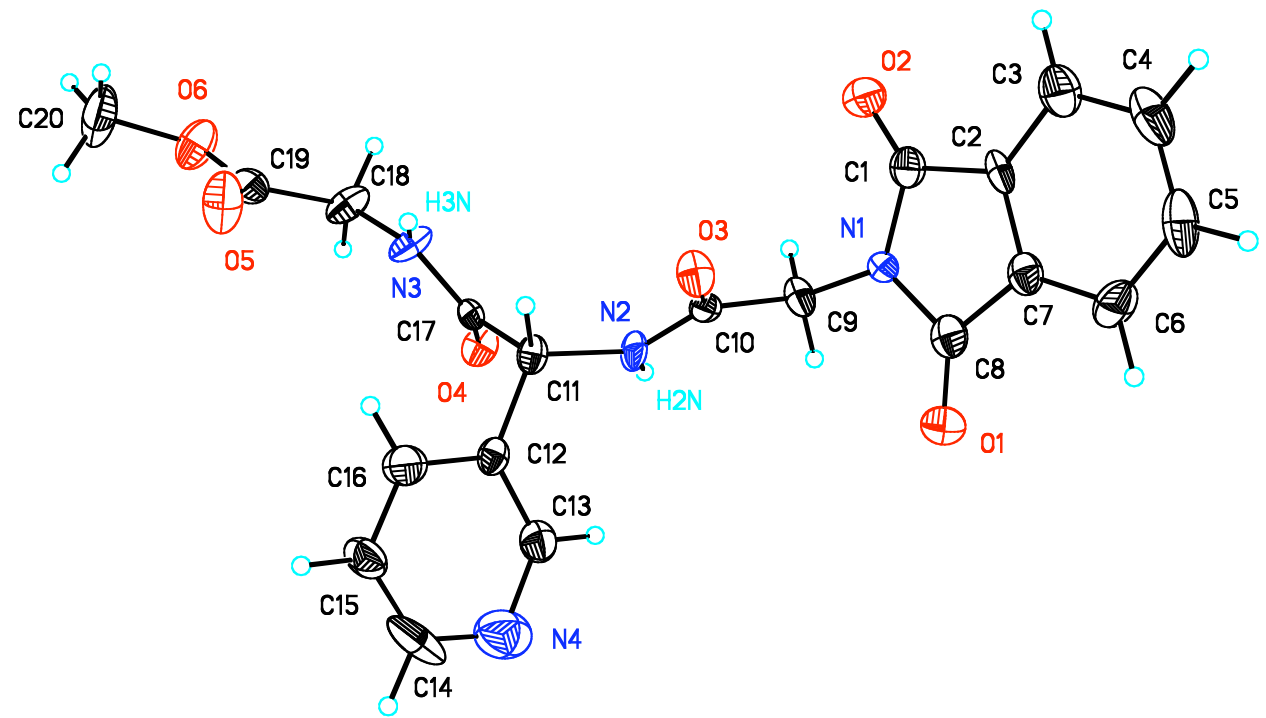

Supplemental Figure 3. Crystal structure of tripeptide 3 . 


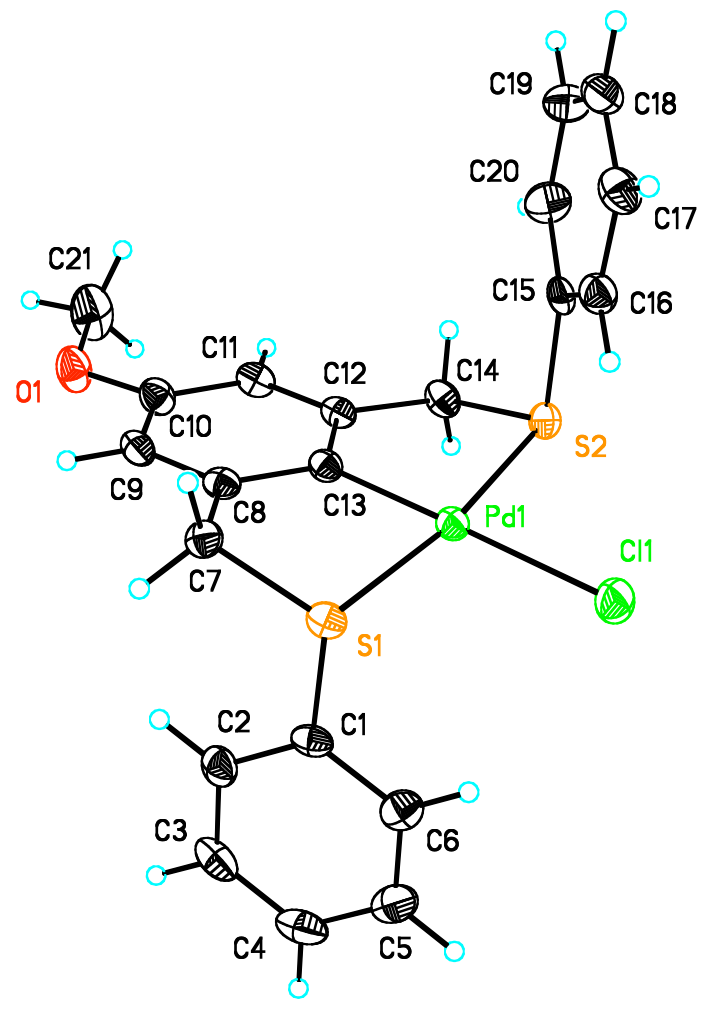

Supplemental Figure 4. Crystal structure of palladated pincer complex 5. 


\section{References}

(1) Kunz, H.; Pfrengle, W. J. Am. Chem. Soc. 1988, 110, 651. 